\title{
Assertivenes, Attention and the Relationship between Swimming Training and Them
}

DOI: $10.26466 /$ opus. 880225

\author{
Mihraç Köroğlu* \\ *Dr. Öğr. Üyesi, Batman Üniversitesi, SporBilimleriFakültesi, Batman/Türkiye \\ E-Posta: mirac kuru@hotmail.com \\ ORCID: 0000-0001-6865-413X \\ **Doç. Dr. DüzceÜniversitesi, SporBilimleriFakültesi, Düzce/Türkiye \\ E-Posta: korkmazyigiter@gmail.com \\ ORCID: $\underline{0000-0002-6933-3466}$
}

\begin{abstract}
This research was conducted to reveal the relationship between swimming and some psychological parameters. The research goal is to define the effect of week-8 swimming training program on the assertiveness and attention levels of high school students aged 15-18 in Sakarya city in Turkey.For investigating the relationship, students (100) aged 15-18 voluntarily participated in the study. All participants divided into two groups as control and experiment. In the process of this research, as data collection tools, Rathus Assertiveness Inventory and Burdon Attention Scale were used to determine scores of the assertiveness and attention levels as pre and post tests. The data obtained in the study, which was conducted with an experimental and sequential design method, were analyzed in the SPSS program and the level of significance was taken as 0.05. In order to compare the pre-test and post-test results of the experimental and control groups, the Mann Whitney U-test was used in independent groups and the Wilcoxon Signed Ranks test in dependent groups. In the assertiveness inventory results, a statistically significant difference was found between the assertiveness pre-test and post-test results of the experimental group and the post-test results of the control group. In the attention level results, a statistically significant difference was found between the attention level pre-test and post-test results of the experimental group and the post-test results of the control group. Research results showed that swimming training program designed 8-week positively affects high school students' assertiveness and attention levels.
\end{abstract}

Key Words: Psychology, Educational courses, Sport Participation, Assertiveness, Attention. 


\section{Atılganlık, Dikkat ve Yüzme Eğitimi ile Aralarındaki İlişki}

*

\section{Öz}

Bu araştırma yüzme sporu ile bazı psikolojik değişkenlerin arasındaki ilişkiyi ortaya çıkarmak için yürütülmüştür. Araştırmanın amacı, Türkiye'nin Sakarya ilindeki 15-18 yaş arası lise öğrencilerinin atılganlık ve dikkat düzeyleri üzerinde 8 haftalık yüzme eğitim programının atılganlık ve dikkat düzeylerine etkisini belirlemektir. Değişkenler arasındaki ilişkiyi incelemek için 15-18 yaş arasında 100 öğrenci gönüllü olarak araştırmaya katılmıştır. Katılımcılar deney ve kontrol grubu olmak üzere ikiye bölünmüş̧ür. Araşttrma sürecinde, veri toplama aracl olarak Rathus Attlganlık envanteri ve Burdan Dikkat ölçeği ön test ve son test olarak uygulanmıştır. Elde edilen veriler SPSS programında analiz edilmiştir. Test sonuçlarının karşılaştırılması için Mann Whitney $U$ test ve Wilcoxon testleri kullanılmıştır. Anlamlılık düzeyi ,05 olarak alınmıştır. Atılganlık envanterinin verileri deney grubu önson test sonuçlarında anlaml düzeyde farklılık olduğunu ortaya çıkarmıştır. Benzer şekilde, dikkat testi verileri deney grubu ön-son test sonuçlarında anlaml düzeyde farklılık olduğunu ortaya çıkarmıştır. Araştırma sonuçları, 8 haftalık olarak tasarlanan yüzme antrenman programının lise öğrencilerinin atılganlık ve dikkat düzeylerini olumlu yönde etkilediğini göstermiştir.

Anahtar Kelimeler : Psikoloji, Eğitimsel Kurslar, SporYapmak, Atılganlık, Dikkat. 


\section{Introduction}

Sport participation have many benefits for people not only physical appearance but also for mood. Participation in sport, recreational or physical activities can improve soma skills too. For instance, assertiveness is one of them and it is a skill to express the feelings. Assertiveness behavior that promotes equality in human relationships, enabling us to act in our own best interests, to stand up for ourselves without undue anxiety, to express honest feelings comfortably, to exercise personal rights without denying the rights of others (Alberti, and Emmons, 2001). Assertiveness also encompasses multidimensional aspects of human expression, including behavior, cognition, and affect. Behaviorally assertive individuals are able to express their emotions, defend their goals, and establish favorable interpersonal relationships (Herzberger et al., 1984; Yong, 2010).

From social skills standpoint, assertiveness is a very important social skill both in professional contexts and in everyday interactions. If rights of people have been violated by the other people, the people feel hurt, aggrieved and upset. Some people find it difficult to be assertive but it is not. This is often related to upbringing in that they may have been raised under a very strict regime by parents, in which as children they were seen and not heard. Also, they have been taught in the period of school that the quiet child was the most approved of by the teacher. It can be difficult in later life to overcome this residue of parental and educational upbringing. However, the results evidence of the research clearly indicated that it is possible to improve assertion skills (Sert, 2003). So how can be improved the assertieveness skill of the people? The literature suggests that variables such as education, experience, workplace, age, health, and past assertiveness training may influence the degree of assertiveness (Sanders, 2007). Improving assertiveness by training is a structural intervention used for social relationship improvement, anxiety disorder therapy, and phobias in children, teenagers and adults (MehrabiZade et. Al. 2009; Mohabe et. al., 2015). What does the assertieveness training included? Period of training with respect to assertiveness is a multi-content method which includes guidance, role playing, feedback, modeling, practice and the review of trained behaviors (McCartan 
andHargie, 2004; Mohabe et. al., 2015). When the people improve their assertiveness skill, what does improved assertiveness skill give them? Many research results have shown that assertiveness training can improve the assertive skills and also improved assertiveness skill improves human relations, affects personality behavior positively, increases positive personal reactions, and reduces social anxiety (Lambertzand Blight, 2016).

Attention is a necessary feature to be successful on a way which you go on in your life. In everyday life, people need to be attentive for not doing wrong things. Attention is a mechanism that controls orienting to, filtering of, and searching for information both in the external and the internal environment (Posner, 1980; ElekesandKiraly, 2021). A study which investigated attention and concentration of students showed that attention and concentration are enhanced following acute bouts of either coordinative exercise or normal sport lessons provided in physical education class in adolescent children (Budde et al., 2008). BidzanBlumaandLipowska, (2018) reviewed Physical Activity and Cognitive Functioning of Children. They presented studies that demonstrate the influence of physical activity on health, especially a positive correlation between sports and cognitive functions. They analyzed the areas of attention, thinking, language, learning, and memory in terms of sports and childhood. Results of the study pointed out that engaging in sports in late childhood positively influences cognitive and emotional functions. Hütterman et al., (2019) developed a method that measures the extent of the attentional focus and perceptual capabilities during performance of a sport-specific task. In their study, the participants were required to judge different player configurations on their left and right sides with varying visual angles between the stimuli. In keeping with the notion that the focus of attention is smaller than the visual field, attentional performance was poorest at the wider viewing angles compared with perceptual performance. In conclusion of their study, the team-sport players were better able to enlarge their attentional focus and make correct decisions more frequently than individual athletes, particularly when a motor response was required. All research showed that some psychological parameters could be improved by giving educational and sportive courses. 
On this purpose, the current study aimed to reveal the relationship between swimming and some psychological parameters.

\section{Methodology}

Participants: A relational and repeated comparative design was used in the present research. This design was used because correlations and differences between four groups. As pre-post test were implemented for state and private school students in the study process. Students were divided into 4 groups as state and private high school. The students in the public school were divided into two groups as experimental and control groups. Same method was used for the private high school too. The research was conducted on high school students attending in Fatih Vocational and Technical Anatolian High School and Private Şahin Anatolian High School in Sakarya Adapazarı District for 2018-2019 education. All participants aged 15-18 (55 Boys and 45 Girls, totally 100) participated in the study voluntarily. The swimming training program was carried out twice a week in Sakarya Swimming Pool. This program was carried out by 4 expert during 8 week. All participants were informed about the process of the study and the research was carried out under the ethical guidelines. Ethical permission (2019/50 Decision Number) was taken from the Duzce University. Also, permission was also obtained from every school principal for the research period. In the procedure of swimming Training, basic swimming training was provided to students. The basic swimming training program consisted of 60-min sessionsfor 2 days per week. Each session began with a 5- to 15-min physically warm-up and dynamic stretches. Period of the study was completed with standing on water, breathing exercises, getting used to water, breathing and coordination in water, footwork and arm exercises with swimming board, arm and breath coordination exercises.

Rathus Assertiveness Inventory: The RAS, created by Dr. Steven A. Rathus in 1973, is the most widely used instrument applied across many disciplines and with several different cultures. The RAS is a 30 -item questionnaire that has been in use since 1973 in multiple assertiveness studies (Adejumo, 1981; Onyeizugbo, 2003; Sanders, 2007). Assertiveness 
responses are graded with a 6-point scale $(+3$, very characteristic of me, extremely descriptive; +2 , rather characteristic of me, quite descriptive; +1 , somewhat characteristic of me, slightly descriptive; -1 , somewhat uncharacteristic of me, slightly non-descriptive; -2 , rather uncharacteristic of me, quite non-descriptive; and -3, very uncharacteristic of me, extremely non-descriptive). A score of +90 represents a very assertive person, wherein a -90 reflects a person with the least assertiveness (Sanders, 2007).

Burdon Attention Scale: Burdon Attention Test was developed by Benjamin Bourdon in 1955. BAS divided into two forms. One of them is implemented by finding and marking certain letters among mixed letters on the page. Other form is implemented by finding and marking specific shapes among mixed shapes on the page. The number of true or false answers in limited time could be taken into consideration. The test was evaluated by determining how many true answers the children marked in a limited time (Brickenkamp, 1975). Students were given letters designed in three paragraph clusters on a page. In first cluster, there were 11 letters "a", 10 letters "b", 10 letters "d" and 10 letters "g". In second cluster, there were 10 letters "a", 10 letters "b", 10 letters "d" and 9 letters "g". In third cluster, there were 10 letters "a", 11 letters "b", 9 letters "d" and 10 letters "g". Students participating in the study were given 3 minutes for each section (Sert, 2010).

Data Analysis: The data collected from the all participants was performed using SPSS 22. Descriptive statistics and frequency analysis of all variables were calculated to determine average of the age, maximum and minimum scores of the assertiveness and attention skills. The data obtained did not showed normal distribution, therefore, the Mann Whitney U-test was used in independent groups and the Wilcoxon Signed Ranks test in dependent groups to differences betweeen pre-post test results. 


\section{Results}

Tabel 1. Descriptive statistics of overall students

\begin{tabular}{llll}
\hline Categories & & $\mathbf{N}$ & $\mathbf{\%}$ \\
\hline Gender & Female & 45 & 45.0 \\
& Male & 55 & 55.0 \\
\hline Age & 15 & 27 & 27.0 \\
& 16 & 31 & 31.0 \\
& 17 & 28 & 28.0 \\
\hline Grade & 18 & 14 & 14.0 \\
& 9th Grade & 31 & 31.0 \\
& 10 th Grade & 34 & 34.0 \\
\hline School Type & 11 th Grade & 35 & 35.0 \\
\hline & State & 50 & 50.0 \\
& Private & 50 & 50.0 \\
\hline
\end{tabular}

As can be seen on Table 1, all students divided into two groups as state (50) and private (50) high schools. Also, the students in state and private high schools divided into expetimental (25) and control (25) groups. Three grade (9th-10th-11th) were determined for the study. 45 students were women and 55 students were men in the research group.

Table 2. Differences between pre and post test results regarding assertiveness in experimental group for State High School

\begin{tabular}{llllll}
\hline & $\mathbf{N}$ & Mean rank & Sum of rank & $\mathbf{z}$ & $\mathbf{p}$ \\
\hline Negative ranks & 0 &, 000 &, 000 & 3,07 &, 000 \\
Pozitive ranks & 11 & 6,00 & 66,00 & & \\
\hline
\end{tabular}

As can be seen on Table 2, in the assertiveness inventory results showed that a statistically significant difference was found between the assertiveness pre-test and post-test results of the experimental group for State High School $(\mathrm{p}<0.05)$.

Table 3. Differences between pre and post test results regarding assertiveness in control group for State High School

\begin{tabular}{llllll}
\hline & $\mathbf{N}$ & Mean rank & Sum of rank & $\mathbf{z}$ & $\mathbf{p}$ \\
\hline Negative ranks & 0 &, 000 &, 000 & 1,14 & 1,57 \\
Pozitive ranks & 2 & 1,50 & 3,00 & & \\
\hline
\end{tabular}

As can be seen on Table 3, in the assertiveness inventory results showed that a statistically significant difference was not found between 
the assertiveness pre-test and post-test results of the control group for State High School( $\mathrm{p}>0.05)$.

Tabe 4. Post test results of assertiveness between experimental and control groups for State High School

\begin{tabular}{llllll}
\hline Groups & $\mathbf{N}$ & Mean rank & Sum of rank & $\mathbf{u}$ & $\mathbf{p}$ \\
\hline Experimental & 25 & 32,34 & 808,50 & 141,50 &, 000 \\
Control & 25 & 18,66 & 466,50 & & \\
\hline
\end{tabular}

As can be seen on Table 4, in the assertiveness inventory results showed that a statistically significant difference was found between the assertiveness post-test results of the experimental and control groups for State High School $(\mathrm{p}<0.05)$.

Table 5. Differences between pre and post test results regarding attention in experimental group for State High School

\begin{tabular}{llllll} 
& $\mathbf{N}$ & Mean rank & Sum of rank & $\mathbf{z}$ & $\mathbf{p}$ \\
\hline Negative ranks & 0 &, 000 &, 000 & 3,46 &, 000 \\
Pozitive ranks & 12 & 6,50 & 78,00 & & \\
\hline
\end{tabular}

As can be seen on Table 5, in the attention scale results showed that a statistically significant difference was found between the attention pretest and post-test results of the experimental group for State High School $(\mathrm{p}<0.05)$.

Table 6. Differences between pre and post test results regarding attention in control group for State High School

\begin{tabular}{llllll}
\hline & $\mathbf{N}$ & Mean rank & Sum of rank & $\mathbf{z}$ & $\mathbf{p}$ \\
\hline Negative ranks & 0 &, 000 &, 000 & 1,73 &, 080 \\
Pozitive ranks & 3 & 2,00 & 6,00 & & \\
\hline
\end{tabular}

As can be seen on Table 6, in the attention scale results showed that a statistically significant difference was not found between the attention pre-test and post-test results of the control group for State High School( $p>0.05)$.

Tabe 7. Post test results of attention between experimental and control groups for State High School

\begin{tabular}{llllll}
\hline Groups & $\mathbf{N}$ & Mean rank & Sum of rank & $\mathbf{u}$ & $\mathbf{p}$ \\
\hline Experimental & 25 & 30,50 & 762,50 & 187,50 &, 000 \\
Control & 25 & 20,50 & 512,50 & & \\
\hline
\end{tabular}


As can be seen on Table 7, in the attention scale results showed that a statistically significant difference was found between the attention posttest results of the experimental and control groups for State High School $(\mathrm{p}<0.05)$.

Table 8. Differences between pre and post test results regarding assertiveness in experimental group for Private High School

\begin{tabular}{llllll}
\hline & $\mathbf{N}$ & Mean rank & Sum of rank & $\mathbf{z}$ & $\mathbf{p}$ \\
\hline Negative ranks & 2 & 9,50 & 19,00 & 3,74 &, 000 \\
Pozitive ranks & 20 & 11,70 & 234,00 & & \\
\hline
\end{tabular}

As can be seen on Table 8 , in the assertiveness inventory results showed that a statistically significant difference was found between the assertiveness pre-test and post-test results of the experimental group for Private High School $(\mathrm{p}<0.05)$.

Table 9. Differences between pre and post test results regarding assertiveness in control group for Private High School

\begin{tabular}{llllll}
\hline & $\mathbf{N}$ & Mean rank & Sum of rank & $\mathbf{z}$ & $\mathbf{p}$ \\
\hline Negative ranks & 2 & 1,50 & 3,00 & 1,41 &, 150 \\
Pozitive ranks & 0 &, 000 &, 000 & & \\
\hline
\end{tabular}

As can be seen on Table 9, in the assertiveness inventory results showed that a statistically significant difference was not found between the assertiveness pre-test and post-test results of the experimental group for Private High School( $\mathrm{p}>0.05)$.

Tabe 10. Post test results of assertiveness between experimental and control groups for Private High School

\begin{tabular}{lllcll}
\hline Groups & N & Mean rank & Sum of rank & U & p \\
\hline Experimental & 25 & 32,20 & 805,00 & 145,00 &, 000 \\
Control & 25 & 18,80 & 470,00 & & \\
\hline
\end{tabular}

As can be seen on Table 10, in the assertiveness inventory results showed that a statistically significant difference was found between the assertiveness post-test results of the experimental and control groups for Private High School $(\mathrm{p}<0.05)$. 
Table 11. Differences between pre and post test results regarding attention in experimental group for Private High School

\begin{tabular}{llllll}
\hline & $\mathbf{N}$ & Mean rank & Sum of rank & $\mathbf{z}$ & $\mathbf{p}$ \\
\hline Negative ranks & 0 &, 000 &, 000 & 3,31 &, 000 \\
Pozitive ranks & 11 & 6,00 & 66,00 & & \\
\hline
\end{tabular}

As can be seen on Table 11, in the attention scale results showed that a statistically significant difference was found between the attention pretest and post-test results of the experimental group for Private High School $(\mathrm{p}<0.05)$.

Table 12. Differences between pre and post test results regarding attention in control group for Private High School

\begin{tabular}{llllll}
\hline & $\mathbf{N}$ & Mean rank & Sum of rank & $\mathbf{z}$ & $\mathbf{p}$ \\
\hline Negative ranks & 2 & 2,50 & 5,00 &, 000 & 1,00 \\
Pozitive ranks & 2 & 2,50 & 5,00 & & \\
\hline
\end{tabular}

As can be seen on Table 12, in the attention scale results showed that a statistically significant difference was not found between the attention pre-test and post-test results of the control group for Private High School( $p>0.05)$.

Tabe 13 Post test results of attention between experimental and control groups for Private High School

\begin{tabular}{llllll}
\hline Groups & N & Mean rank & Sum of rank & U & p \\
\hline DeneyGrubu & 25 & 32,00 & 800,00 & 150,00 &, 000 \\
KontrolGrubu & 25 & 19,00 & 475,00 & & \\
\hline
\end{tabular}

As can be seen on Table 13, in the attention scale results showed that a statistically significant difference was found between the attention posttest results of the experimental and control groups for Private High School $(\mathrm{p}<0.05)$.

\section{Discussion}

The research goal is to define the effect of week-8 swimming training program on the assertiveness and attention levels of high school students aged 15-18.This research was conducted on the students (100) aged 15-18 voluntarily participated in the study. The data obtained the research 
come some trustable results out for future studies. In the assertiveness inventory results, a statistically significant difference was found between the assertiveness pre-test and post-test results of the experimental group and the post-test results of the control group. In the attention level results, a statistically significant difference was found between the attention level pre-test and post-test results of the experimental group and the post-test results of the control group. The recreational activities have positive effects on assertiveness of university students.

Budde et al. (2008) conducted a study related attention and concentration. In their study, a total of 115 pupils aged 13-16 years of an elite performance school were randomly assigned to an experimental and a control group and were tested for attention and concentration. Groups in that study performed the attention and concentration test after a regular school lesson (pre-test) and then after either 10 minutes of coordinative exercise (experimental group), or following a normal sport lesson (control group). Concentration and attention task scores were higher following either coordinative exercise or a normal sport lesson, in comparison to following a regular school lesson. Larger test score improvements were observed in the coordinative exercise group in comparison to the normal sport lesson group, though heart rate was similar in both groups. Their study results showed that attention and concentration were enhanced following acute bouts of either coordinative exercise or normal sport lessons provided in physical education class.Also the results of the study pointed out that the coordinative exercise may activate parts of the brain responsible for attention and concentration. So it can be concluded that exercising regularly and coordinatively can be one of the most effective ways to improve concentration and attention.Qio et al., (2018) studied to investigate whether performance in a multiple object tracking (MOT) task could be improved incrementally with sports expertise, and whether differences between experienced and less experienced athletes, or non-athletes, were modulated by load. The results of their study suggested that the effects of expertise in team ball sports could transfer to a non-sports-specific attention task. These transfer effects to general cognitive functions occur only in elite athletes with extensive training under higher attentional load. Memmert and Simons (2009), found in their study that all basic attention tasks are largely independent provides pre- 
liminary support for the idea that attentional breadth, tracking performance, and inattentional blindness are distinct attentional processes. Their results demonstrate that sports expertise effects are unrelated to basic differences in attention-expertise does not appear to produce differences in basic attention and basic differences in attention do not appear to predict eventual expertise. Further experiments could focus on the ways in which more specific attentional strategies and processes contribute to sports performance. Regular swimming training program makes a significant positive difference in terms of assertiveness and attention. Swimming is an effective way to break your routine life cycle. As well as releasing endorphins in the brain, physical activity helps to relax the muscles and relieve tension in the body. Since the body and mind are so closely linked, when your body feels better so, too, will your mind.Physical activity immediately boosts the brain's dopamine, norepinephrine, and serotonin levels, all of which affect focus and attention (Segal et al. 2017).

Mohabi et al. (2015) investigated the effect of assertiveness training on student's academic anxiety. The results of their study showed that anxiety levels and decisiveness in the target group were moderate to high and it is seen as a significant reverse relationship between these two factors $(r=-0.69$ and $p<0.001)$. The research results also showed that there was a significant anxiety decrease in the experimental group after the intervention. On the one hand, there was a significant increase in decisiveness for both groups, but there was not a significant difference between academic anxiety and assertiveness in the control group before and after the intervention. Due to a significant decrease in anxiety and increased decisiveness in the experimental group, it can be claimed that assertiveness training is an effective non-pharmacological method for reducing academic anxiety and it can improve academic performance (Mohabi et al., 2012). Lin et al. (2004) evaluated the effect of an assertiveness training program on nursing and medical students' assertiveness, self-esteem, and interpersonal communication satisfaction. In their study, participants in the experimental group received eight 2-h sessions of assertiveness training once a week. Their study pointed out that the assertiveness and selfesteem of the experimental group were significantly improved in nursing and medical students after assertiveness training, although interper- 
sonal communication satisfaction of the experimental group was not significantly improved after the training program. Eslami et al. (2016) studied about effectiveness of assertiveness training on the levels of stress, anxiety, and depression of high school students. Their study results showed that conducting assertive training in high school students decreases their anxiety, stress, and depression. Given that high school years are among the most sensitive stages of one's life plus the fact that conducting such training programs besides their safe and low cost nature are effective and practical. Study recommended that such educational programs related the assertiveness can be carried out among high school adolescents. Kadri et al. (2019) investigated the effect of taekwondo practice on cognitive function in adolescents with attention deficit hyperactivity disorder. In conclusion of the study, taekwondo practice increased selective attention in adolescents with attention deficit hyperactivity disorder. They pointed out that practitioners should implement martial art programs in their general plans to favorably influence attention and health in adolescents with attention deficit hyperactivity disorder. Yiğiter, (2013) investigated improving the nursing students' assertiveness skills byparticipating in recreational physical activities. In his study, 63 university students participated in the study and were ramdomly assigned to experimental (Mage $=18,90 \pm 1,09$ ) and control (Mage $=18,76 \pm 1,03$ ) groups. The experimental group participated in the recreational physical activities program which was conducted in two sessions each lasting one hour within a week. During that period, the control group of the study did not participate in any regular recreational physical activity program. The results of the study pointed out that the recreational physical activities positively affected the assertiveness on nursing students. A few limitations must be taken into consideration. Covid-19 affected the social life all over the world. Therefore, the researcher reached limited students in state and private high schools. But despite of all negative conditions the study conducted in a good way. All data collected the current study and literature showed that physical activities and educational courses can influence the assertiveness and attention levels of the students. All research indications would be useful in developing training programs for students, aimed at improving assertiveness and attention skills of the students. 


\section{References}

Alberti, R. and Emmons, M. (2001). Your perfect right: Assertiveness and equality in your life and relationships. Atascadero, CA: Impact Publishers, Inc.

Bidzan-Bluma, I. andLipowska, M. (2018). Physical activity and cognitive functioning of children: A systematic review. International Journal of Environmental Research and Public Health, 15(4), 800.

Brickenkamp R, Bleck I, Dzida W, Heinrich P, Hellwig HJ, Krüger Naumann R, Rothe R, Speck D, Speck R, andThiede L. (1975). Handbuchpsychologischerundpaedagogischertests. Göttingen: Verlag fürPsychologie.

Budde, H., Voelcker-Rehage, C., Pietrayk-Kendziorra, S., Ribeiro, P. andTidow, G. (2008). Acute coordinative exercise improves attentional performance in adolescents. Neuroscience Letter. 441, 219-223.

Elekes, F. andKirály, I. (2021). Attention in naïve psychology. Cognition,206, 104-480.https://doi.org/10.1016/j.cognition.2020.104480.

Eslami, A. A., Rabiei, L., Afzali, S. M., Hamidizadeh, S. and Masoudi, R. (2016). The effectiveness of assertiveness training on the levels of stress, anxiety, and depression of high school students. Iranian Red Crescent Medical Journal, 18(1), doi: 10.5812/ircmj.21096.

Herzberger, S. D., Chan, E. and Katz, J., 1984. The development of an assertiveness selfreport inventory. Journal of Personality Assessment,48(3), 317-323.

Hüttermann, S., Ford, P.R., Williams, A.M., Varga, M., and Smeeton, N.J. (2019). Attention, perception, and action in a simulated decisionmaking task.Journal of Sport and Exercise Psychology, 41(4), 230-241. 10.1123/jsep.2018-0177.

Kadri, A., Slimani, M., Bragazzi, Tod, D. andAzaiez, F. (2019). The effect of taekwondo practice on cognitive function in adolescents with attention deficit hyperactivity disorder. International Journal of Environmental Research and Public Health, 16(2), 204.

Lambertz, M.M, and Blight, M.G. (2016). You don't have to like me, but you have to respect me: the İmpacts of assertiveness, cooperativeness, and group satisfaction in collaborative assignments. Business and Professional Communication Quarterly,79(2), 180-199.

Lin, Y. R., Shiah, I. S., Chang, Y. C., Lai, T. J., Wang, K. Y. and Chou, K. R., (2004). Evaluation of an assertiveness training program on nursing and medical students' assertiveness, self-esteem, and interpersonal 
communication satisfaction. Nurse Education Today,24(8), 656-65. doi: 10.1016/j.nedt.2004.09.004.

MehrabiZade, M. H., Taghavi, S. F., Attari, Y. A. (2009). Effect of group assertive training on social anxiety, social skills and academic performance of female students. Journal of Behavioral Sciences,1, 59-64.

Memmert, D. and Simons, D.J. (2009). Psychology of sport and exercise, 10(1):146-151. DOI: 10.1016/j.psychsport.2008.06.002.

McCartan, K., andHargie, O. D. (2004). Assertiveness and caring: Are they compatible? Journal Clinical Nurse, 13, 707-13.

Mohebi, S., Sharifirad, G. H. R., Shahsiah, M., Botlani, S., Matlabi, M. andRezaeian, M. (2012). The effect of assertiveness training on student's academic anxiety. Journal Pakistan Medical Association, 62(3-2), 37-41.

Posner, M.I.(1980).Orienting of attention. Quarterly Journal of Experimental Psychology, 32(1), 3-25. https://doi.org/10.1080/00335558008248231.

Qiu F, Pi Y, Liu K, Li X, Zhang J, Wu Y. (2018). Influence of sports expertise level on attention in multiple object tracking. Peer Journal, 6, 5732 https://doi.org/10.7717/peerj.5732.

Sanders R.L. (2007). Assertive Communication Skills With Nurses in a Rural Setting. Master' Thesis. The University of Wyoming. M. S. Whitney School of Nursing. Nurse Education in Practice, 3, 30-42.

Sert, A.Ş. (2003). The effect of an assertiveness training on the assertiveness and self esteem level of 5th grade children. Orta Doğu Teknik Üniversitesi, Sosyal Bilimler Enstitüsü, Ankara.

Sert, A. (2010). İlköğretimde Altıncı Sinıf Öğrencilerinin Okuduğunu Anlama Becerilerinin Bazı Değişkenler Açısından İncelenmesi. Selçuk Üniversitesi, Eğitim Bilimleri Enstitüsü, Konya.

Segal, J., Smith, M., Segal, R., and Robinson, L. (2019). Stress Symptoms, Signs, and Causes. (online) Available at https:// www.helpguide.org larticles/stress/stress-symptoms-signs-and-causes.htm.

Yiğiter, K. (2013). Improving the nursing students' assertiveness skills by participating in recreational physical activities. International Journal of Sport Studies, 3(3), 258-262.

Yong, F. (2010). A Study on the assertiveness and academic procrastination of english and communication students at a private university. American Journal of Scientific Research, 9, 62-72. 


\section{Citation Information}

Köroğlu, M. and Yiğiter, K.(2021).Assertivenes, attention and the relationship between swimming training and them. OPUSInternational Journal of Society Research, 18(41), 3066-3081. DOI: 10.26466/opus.880225. 